\title{
GABA AND BENZODIAZEPINE RECEPTORS IN BASAL GANGLIA FUNCTION
}

\author{
ANNE B. YOUNG*, HELEN S. PAN, BRIAN J. CILIAX and JOHN B. PENNEY \\ Departments of Neurology and Pharmacology, University of Michigan, Ann Arbor, MI 48104 (U.S.A.)
} (Received February 27th, 1984; Accepted April 2nd, 1984)

Key words: $\gamma$-aminobutyric acid - benzodiazepine receptors - basal ganglia - opiate receptors

GABA and its associated benzodiazepine interactions play an important role in basal ganglia function. Distinctive GABA, benzodiazepine and opiate receptor changes occur in response to striatal lesions and in the human neurodegenerative disorder, Huntington's disease (HD). In animal experiments, the in vivo administration of $\left[{ }^{3} \mathrm{H}\right]$ flunitrazepam labels benzodiazepine receptors and can demonstrate the receptor changes seen after striatal lesions. It should be possible to measure these receptors in vivo in humans using positron-emission tomographic scanning.

The role of $G A B A$ in basal ganglia function. As in the rest of the nervous system, GABA has been found to play an important role in basal ganglia function $[5,9,11,13,14,20]$. The caudate nucleus and putamen have high levels of GABA and glutamic acid decarboxylase (GAD) activity as do the lateral and medial globus pallidus and the substantia nigra pars reticulata $[5,14,17]$. The caudate nucleus and putamen receive excitatory input from all regions of the cerebral cortex and from the parafascicular nuclei of thalamus $[5,14]$. They receive inhibitory input from the substantia nigra pars compacta and the raphe nuclei. The outputs of caudate nucleus and putamen go to the lateral and medial globus pallidus (LGP and MGP) and also to the pars reticulata of substantia nigra (SNr). The MGP and $\mathrm{SN}_{\mathrm{r}}$ project to ventral medial thalamus, which in turn projects to cerebral cortex.

A large proportion of striatal output cells are medium-sized spiny neurons which contain GAD-like immunoreactivity [17]. They have extensive local axon collaterals and send output to LGP, MGP and SNr $[5,9,14]$. These GABA neurons make direct connections with LGP, MGP and SNr neurons which also contain GABA [10,14]. The GABAergic neurons in LGP project to subthalamic nucleus and those in MGP and $\mathrm{SNr}$ project to thalamus.

\footnotetext{
*Author for correspondence at: Neuroscience Building, 1103 East Huron Street, Ann Arbor, MI 48104, U.S.A.
} 
There are many other transmitters and neuromodulators in caudate-putamen in addition to GABA [5]. Only two important classes of modulators, the opiate peptides and the benzodiazepines, will be discussed here. The benzodiazepines interact with specific receptors in brain which are physiologically, pharmacologically and biochemically related to GABA receptors $[7,8]$. Most evidence would suggest that the benzodiazepines interact with a subunit of the GABA receptor-chloride ionophore receptor complex [7,8]. Leu-enkephalin, Met-enkephalin and dynorphin are all opiate peptides that are present in the caudate-putamen and at least some of these peptides appear to coexist in GABA neurons $[4,5,9,10]$. These peptides may control the release of GABA or modify the action of GABA on the postsynaptic neurons. The presence of opiate peptides in the GABAergic striatal neurons distinguishes these GABA cells from those in MGP and $\mathrm{SNr}$ which do not contain opiate peptides [9]. Further work is needed before the role of these peptides in striatal function is defined.

The GABAergic output neurons of the caudate-putamen make synapses on GABAergic MGP/SNr cells [10]. Neurophysiologically, the MGP and SNr neurons are spontaneously active and the caudate-putamen output inhibits their activity [14]. The caudate-putamen is therefore in a position to function as a disinhibitor of the thalamus [14,18]. Disinhibition of the thalamus is one mechanism by which the caudate-putamen may function to facilitate a particular behavior and surround-inhibit conflicting behaviors via local axon collaterals [14]. Diseases of the basal ganglia cause a disruption of this function. Parkinson's disease, which causes a slowness of movement, tremor and rigidity, results from loss of dopaminergic inhibitory input to caudate-putamen and therefore an over-activity of caudateputamen GABAergic inhibitory output to MGP and SNr. Patients with Parkinson's disease appear to have excessive reinforcement of ongoing behaviors and difficulty stopping one motor behavior to initiate a new one. Interestingly, atypical parkinsonism is frequently caused by pathology directly in the MGP and $\mathrm{SNr}$, thereby directly disrupting GABAergic MGP and SNr output to thalamus [14].

Huntington's disease (HD), often thought of as the clinical opposite of Parkinson's disease, is characterized by excessive motor activity, loss of motor persistence and difficulty carrying out coordinated motor tasks. In this disease, the caudateputamen shows profound neuronal loss and the MGP and SNr are deafferented [14, 19]. Unwanted behaviors are no longer suppressed and ongoing ones are not facilitated via disinhibition of the thalamus resulting in a breakdown of coordination and an excess of random movements.

Receptors in Hungtinton's disease and rats with striatal kainate lesions. We have investigated neurotransmitter receptors in animal models of Huntington's disease and postmortem tissues of patients dying with Huntington's disease. Although investigators have studied receptors in these preparations using homogenate techniques, only limited attention has been paid to striatal projection areas and to quantitative measurements in each sample $[4,16,20]$. We have focused on quantitative 
autoradiographic measurements of GABA, benzodiazepine and opiate receptors in these preparations to see whether the drug receptor changes are characteristic of the particular disease.

Using the kainic acid model of Huntington's disease in rats [3], we have examined receptors both acutely and chronically after lesions of the striatum. Acutely (1 week) after striatal kainate lesions, GABA receptors, as measured by $\left[{ }^{3} \mathrm{H}\right]$ muscimol binding, decrease locally in striatum but increase in globus pallidus (GP) (the murine counterpart of LGP), entopeduncular nucleus (EPN) (the murine counterpart of MGP) and SNr [11]. Benzodiazepine receptors decrease locally in striatum at 1 week but show no change in the striatal projection areas [12]. In contrast, opiate receptors as measured by $\left[{ }^{3} \mathrm{H}\right] \mathrm{D}-\mathrm{Ala}-\mathrm{D}-\mathrm{Leu}-\mathrm{enkephalin}$ (DADL) binding decrease locally in striatum and in the striatal projection areas [1]. Chronically (8 weeks) after the lesions, $\left[{ }^{3} \mathrm{H}\right]$ muscimol binding in both striatum and striatal projection areas is virtually identical to that seen in the acute animals [11]. $\left.{ }^{3} \mathrm{H}\right]$ Flunitrazepam binding is now decreased in striatum and increased in GP, EPN and SNr [12] (Table I). $\left[{ }^{3} \mathrm{H}\right] \mathrm{DADL}$ binding is decreased in all regions (Table I). The results suggest that destruction of striatal neurons leads to local receptor loss because of the loss of neuronal cell bodies and axon collaterals. In striatal projection areas, GABA and benzodiazepine receptors increase on the postsynaptic neurons in response to deafferentation, and opiate receptors decrease presumably because of their location on the striatal presynaptic terminals (Fig. 1). No changes in receptor affinity for any of the ligands were seen in any region $[1,11,12]$.

\section{TABLE I}

BENZODIAZEPINE AND OPIATE RECEPTORS IN BASAL GANGLIA OF RATS 8-12 WEEKS AFTER UNILATERAL STRIATAL KAINATE LESIONS

Values represent $\mathbf{B}_{\max }$ values \pm S.E.M. for each ligand in a particular region. $\mathbf{B}_{\max }$ data were derived by exposing serial sections of a region to 6 concentrations of ligand and then analyzing the autoradiographic data by Scatchard analysis as previously described $[1,11,12] .{ }^{*} P<0.02,{ }^{* *} P<0.001$, significantly less than control by two-tailed paired $t$-test.

\begin{tabular}{|c|c|c|c|}
\hline \multirow[b]{2}{*}{ Ligand } & \multicolumn{3}{|c|}{$\mathrm{B}_{\max }$ of bound ligand ( $\mathrm{fmol} / \mathrm{mg}$ protein) } \\
\hline & Striatum & Glubus pallidus & $\begin{array}{l}\text { Substantia nigra } \\
\text { pars reticulata }\end{array}$ \\
\hline \multicolumn{4}{|c|}{$\begin{array}{l}{\left[{ }^{3} \mathrm{H}\right] \text { Flunitrazepam }(n=8)} \\
(\mathrm{fmol} / \mathrm{mg} \text { protein) }\end{array}$} \\
\hline Lesioned & $200 \pm 40^{* *}$ & $1020 \pm 160^{*}$ & $2000 \pm 320^{*}$ \\
\hline Control & $650 \pm 90$ & $720 \pm 110$ & $1500 \pm 380$ \\
\hline \multicolumn{4}{|c|}{$\begin{array}{l}{\left[{ }^{3} \mathrm{H}\right] \mathrm{DADL}(\mathrm{n}=6)} \\
(\mathrm{fmol} / \mathrm{mg} \text { protein) }\end{array}$} \\
\hline Lesioned & $35 \pm 6^{* *}$ & $29 \pm 2^{*}$ & $56 \pm 10^{*}$ \\
\hline Control & $195 \pm 24$ & $40 \pm 2$ & $76 \pm 12$ \\
\hline
\end{tabular}




\section{CAUDATE MGP/ PUTAMEN SNr VM \\ NORMAL

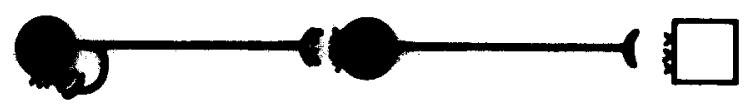 \\ LESIONED}

Fig. 1. Schematic of GABAergic connections in basal ganglia. GABA (plus opiate) neurons in caudateputamen send inhibitory projections to MGP/SNr. The MGP/SNr neurons are GABAergic in turn and project to ventral medial thalamus. Opiate receptors ( $\bullet$ appear to be located presynaptically on caudate-putamen neurons and nerve terminals and therefore decrease in both caudate-putamen and $\mathrm{MGP} / \mathrm{SNr}$ after striatal lesions. GABA and benzodiazepine receptors $(\Lambda)$ are located postsynaptically on caudate-putamen and MGP/SNr neurons and decrease locally but increase in MGP/SNr after striatal lesions.

The same autoradiographic methods used in the animal studies were applied to the investigation of receptors in postmortem tissues of controls and patients dying of Huntington's disease (Table II). Virtually identical changes were seen in the

\section{TABLE II}

GABA, BENZODIAZEPINE AND OPIATE RECEPTOR BINDING IN CONTROL AND HUNTINGTON'S DISEASE BRAINS ${ }^{a}$

$\left[{ }^{3} \mathrm{H}\right]$ Muscimol binding was used to measure GABA receptors, $\left[{ }^{3} \mathrm{H}\right]$ flunitrazepam binding to measure benzodiazepine receptors and $\left[{ }^{3} \mathrm{H}\right] \mathrm{DADL}$ binding to measure opiate receptors as previously described $[13,15,21]$. The values represent the $\mathrm{B}_{\max } \pm$ S.E.M. of binding. No significant changes in $K_{d}$ were seen. ${ }^{*} P<0.02$ by two-tailed independent $t$-test.

\begin{tabular}{|c|c|c|c|}
\hline Ligand & Striatun & & Lateral globus pallidus \\
\hline \multicolumn{4}{|c|}{$\left[{ }^{3} \mathrm{H}\right]$ Muscimol (fmol $/ \mathrm{mg}$ protein) } \\
\hline Control $(n=5)$ & 1.16 & 0.10 & $0.62 \pm 0.13$ \\
\hline$H D(n=6)$ & 0.65 & $0.16^{*}$ & $1.28 \pm 0.48^{*}$ \\
\hline \multicolumn{4}{|c|}{$\left[{ }^{3} \mathrm{H}\right]$ Flunitrazepam (pmol/mg protein) } \\
\hline Control $(n=5)$ & 0.54 & 0.10 & $0.43 \pm 0.05$ \\
\hline $\mathrm{HD}(\mathrm{n}=6)$ & 0.24 & $0.14^{*}$ & $0.74 \pm 0.19^{*}$ \\
\hline \multicolumn{4}{|c|}{$\left[{ }^{3} \mathrm{H}\right]$ DADL (fmol/mg protein) } \\
\hline Control $(n=5)$ & 350 & \pm 100 & \pm 10 \\
\hline $\mathrm{HD}(\mathrm{n}=5)$ & 103 & $\pm 31^{*}$ & $\pm 1^{*}$ \\
\hline
\end{tabular}

${ }^{a}$ All brains were removed and frozen within $24 \mathrm{~h}$ of death. Average age \pm S.D. of controls was $63 \pm$ 8 years and of HD $64 \pm 11$ years. None of the controls was on centrally active drugs. Two of the HD patients were on neuroleptics. Four controls died from sudden cardiac death and one during coronary artery surgery. All HD patients had family histories of HD and died of complications of HD. 

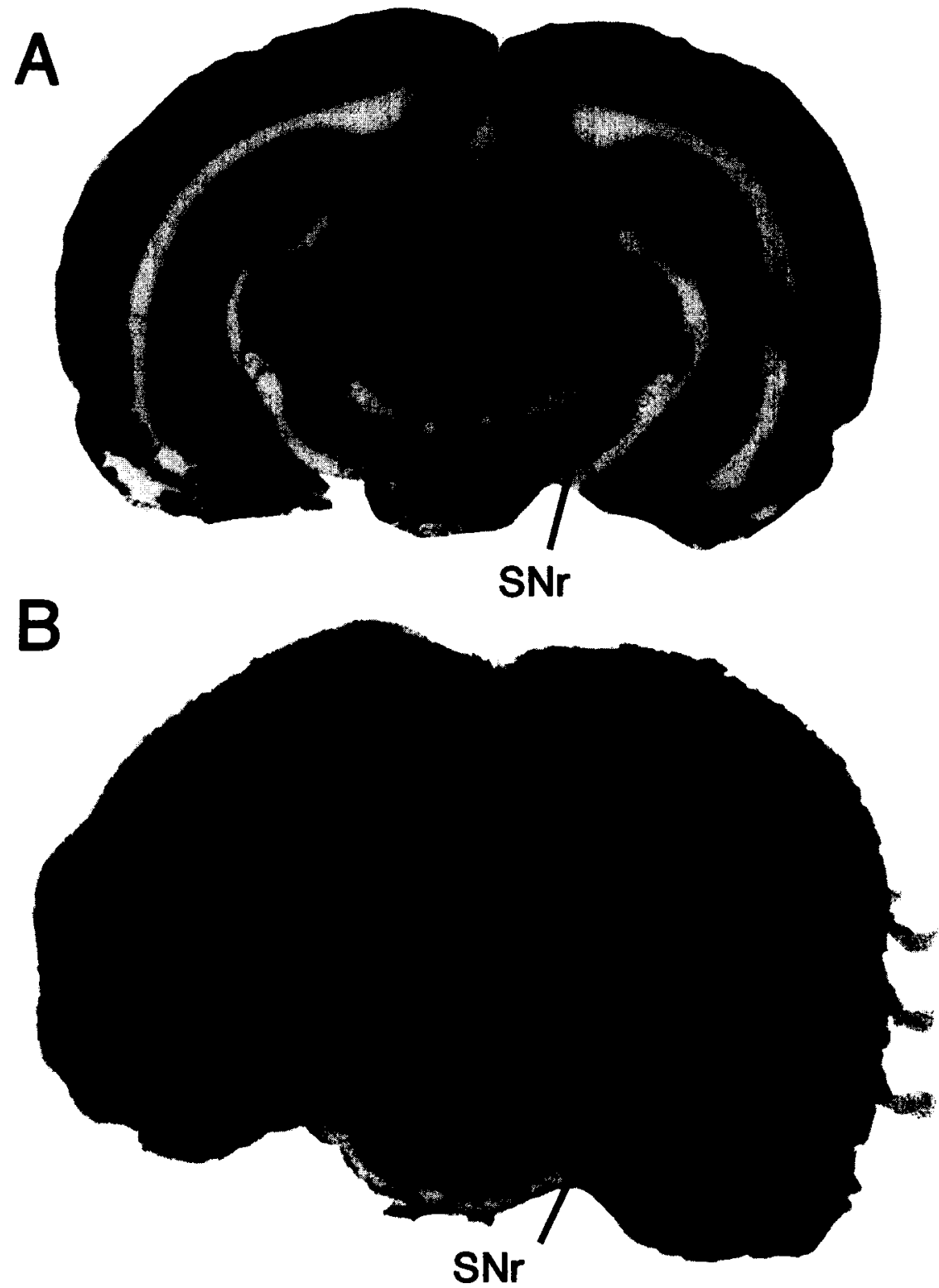

Fig. 2. 'In vitro' and 'in vivo' images of benzodiazepine binding in the substantia nigra pars reticulata (SNr) of rats with left striatal kainate lesions. In both images the left ( $\mathrm{SNr}$ ) has significantly more binding than the right. A: 'In vitro' binding: 3 months post-lesion this $20-\mu \mathrm{m}$ frozen section through $\mathrm{SNr}$ was incubated in $4 \mathrm{nM}\left[{ }^{3} \mathrm{H}\right]$ flunitrazepam in $50 \mathrm{mM}$ Tris- $\mathrm{HCl}\left(\mathrm{pH} \mathrm{7.4)}\right.$ for $30 \mathrm{~min}$ at $37^{\circ} \mathrm{C}$. The section was then rinsed twice in cold buffer for $5 \mathrm{~min}$ and exposed to Ultrofilm $3 \mathrm{H}$ (LKB) for 10 days. Non-specific binding in the presence of $1 \mu \mathrm{M}$ clonazepam represented less than $5 \%$ of total binding. B: 'In vivo' binding: 3 months post-lesion $400 \mu \mathrm{Ci}\left[{ }^{3} \mathrm{H}\right]$ flunitrazepam in saline was given in an intravenous bolus followed by a $10 \mu \mathrm{Ci} / \mathrm{min}$ infusion. The animal was decapitated at $10 \mathrm{~min}$, the brain was frozen and sectioned on a cryostat. This $20-\mu \mathrm{m}$ section through $\mathrm{SNr}$ was exposed to Ultrofilm $3 \mathrm{H}$ (LKB) for 30 days. 
human material as in the chronic animal preparations $[13,15,21]$. Thus GABA and benzodiazepine receptors decrease in striatum and increase in globus pallidus, and opiate receptors decrease in both striatum and globus pallidus. The receptor changes appear to occur early in Huntington's disease as evidenced by the observation of decreased striatal and increased pallidal GABA and benzodiazepine receptors in the brains of two Huntington's disease cases who died early in the disease. These brains showed no gross atrophy and only minimal neuronal cell loss in caudate-putamen at autopsy [21].

In vivo imaging of receptor changes in rat. The distinctiveness of the drug receptor changes in Huntington's disease suggests that measurement of receptors in vivo might show changes early in the disease and, possibly, even presymptomatically. With the recent discovery of a linkage marker in Huntington's disease [6], it will be important to define objective measures of the earliest changes in brain so that potential therapies can be started prior to substantial brain damage. It would then be possible to assess prospectively the deterioration of brain function and the ability of therapies to retard or halt the progression of disease.

We have investigated the ability of in vivo administration of $\left[{ }^{3} \mathrm{H}\right]$ flunitrazepam to image benzodiazepine receptor changes in striatal lesioned rats [B.J. Ciliax, H.S. Pan, J.B. Penney and A.B. Young, in preparation]. $\left[{ }^{3} \mathrm{H}\right]$ Flunitrazepam enters brain rapidly and binds to benzodiazepine receptors. Non-specific binding is defined as binding in the presence of excess clonazepam $(5 \mathrm{mg} / \mathrm{kg})$ administered intravenously $30 \mathrm{~min}$ prior to $\left[{ }^{3} \mathrm{H}\right]$ flunitrazepam administration. After a bolus injection followedby a constant infusion, $\left[{ }^{3} \mathrm{H}\right]$ flunitrazepam binding equilibrates within $30 \mathrm{~min}$ and shows specific-to-nonspecific binding ratios of $2: 1$. Non-specific binding can be directly related to the circulating blood concentration of $\left[{ }^{3} \mathrm{H}\right]$ flunitrazepam and therefore estimated from blood-curve measurements. Administration of $\left[{ }^{3} \mathrm{H}\right]$ flunitrazepam to 12-week striatal-lesioned animals demonstrates decreased binding in striatum and increased binding in globus pallidus and substantia nigra pars reticulata similar to that seen by in vitro techniques (Fig. 2). Previous investigators have successfully labeled flunitrazepam with carbon-11 in the methyl position [2]. This agent therefore shows great promise as an imaging agent for positron-emission tomographic scanning in humans.

Supported by USPHS Grants NS 00464, NS 00420, the Hereditary Disease Foundation, the Huntington's Disease Foundation of America, and the McKnight Foundation.

1 Abou-Khalil, B., Penney, J.B. and Young, A.B., Evidence for the presynaptic localization of opiate receptors on striatal efferent fibers, Brain Res., in press.

2 Comar, D., Maziere, M., Cepeda, C., Godot, J.-M., Menini, C. and Naquet, R., The kinetics and displacement of $\left[{ }^{11} \mathrm{C}\right]$ flunitrazepam in the brain of the living baboon, Europ. J. Pharmacol., 75 (1981) 21-26.

3 Coyle, J.T., Neurotoxic amino acids in human degenerative disorders, Trends Neurosci., 5 (1982) 287-288. 
4 Emson, P.C., Arregui, A., Clement-Jones, V., Sandberg, B.E.B. and Rossor, M., Regional distribution of methionine-enkephalin and substance P-like immunoreactivity in normal human brain and in Huntington's disease, Brain Res., 199 (1980) 147-160.

5 Graybiel, A.M. and Ragsdale, Jr., C.W., Biochemical anatomy of the striatum. P.C. Emson (Ed.), Chemical Neuroanatomy, Raven Press, New York, 1983, pp. 427-504.

6 Gusella, J.F., Wexler, N.S., Conneally, P.M., Naylor, S.L., Anderson, M.A., Tanzi, R.E., Watkins, P.C., Ottina, K., Wallace, M.R., Sakaguchi, A.Y., Young, A.B., Shoulson, I., Bonilla, E. and Martin, J.B., A polymorphic DNA marker genetically linked to Huntington's disease, Nature (Lond.), 306 (1983) 234-238.

7 Haefely, W., Polc, P., Pieri, L., Schaffner, R. and Laurent, J.-P., Neuropharmacology of benzodiazepines: synaptic mechanisms and neural basis of action. In E. Costa (Ed.), The Benzodiazepines: From Molecular Biology to Clinical Practice, Raven Press, New York 1983, pp. 21-66.

8 Mohler, H. and Richards, J.G., Benzodiazepine receptors in the central nervous system. In E. Costa (Ed.), The Benzodiazepines: From Molecular Biology to Clinical Practice, Raven Press, New York, 1983, pp. 93-116.

9 Oertel, W.H., Riethmuller, G., Mugnaini, E., Schmechel, D.E., Weindl, A., Gramsch, C. and Herz, A., Opioid peptide-like immunoreactivity localized in GABAergic neurons in rat neostriatum and central amygdaloid nucleus, Life Sci., 33, Suppl. I (1983) 73-76.

10 Oertel, W.H. and Mugnaini, E., Immunocytochemical studies of GABAergic neurons in rat basal ganglia and their relations to other neuronal systems, Neurosci. Lett.,

11 Pan, H.S., Frey, K.A., Young, A.B. and Penney, J.B., Changes in $\left[{ }^{3} \mathrm{H}\right]$ muscimol binding in substantia nigra, entopeduncular nucleus, globus pallidus, and thalamus after striatal lesions as demonstrated by quantitative receptor autoradiography, J. Neurosci., 3 (1983) 1189-1198.

12 Pan, H.S., Penney, J.B. and Young, A.B., Autoradiography of $\left[{ }^{3} \mathrm{H}\right]$ flunitrazepam binding in globus pallidus, entopeduncular nucleus and substantia nigra after striatal kainic acid lesions in the rat, Soc. Neurosci. Abstr., 9 (1983) 408.

13 Penney, J.B. and Young, A.B., Quantitative autoradiography of neurotransmitter receptors in Huntington disease, Neurolgy, 32 (1982) 1391-1395.

14 Penney, J.B. and Young, A.B., Speculation on the functional anatomy of basal ganglia disorders, Ann. Rev. Neurosci., 6 (1983) 73-94.

15 Penney, J.B., Young, A.B., Walker, F.O. and Shoulson, I., Quatitative autoradiography of opiate receptors in Hungtington's disease, Neurology, 34 (1984) 153.

16 Reisine, T.D., Beaumont, K., Bird, E.D., Spokes, E. and Yamamura, H.I., Huntington's disease: alterations in neurotransmitter receptor binding in the human brain, Advanc. Neurol., 23 (1979) 717-726.

17 Ribak, C.E., Vaughn, J.E. and Roberts, E., The GABA neurons and their axon terminals in rat corpus striatum as demonstrated by GAD immunocytochemistry, J. comp. Neurol., 187 (1979) 281-284.

18 Roberts, E., Some thoughts about GABA and the basal ganglia. In M.D. Yahr (Ed.), The basal Ganglia, Raven Press, New York, 1976, pp. 191-203.

19 Spokes, E.G.S., The neurochemistry of Huntington's chorea, Trends Neurosci., 4 (1981) 115-118.

20 Waddington, J.L. and Cross, A.J., Characterization of denervation supersensitivity in the striatonigral GABA pathway of the kainic acid-lesioned rat and in Huntington's disease, Brain Res. Bull., 5 (1980) 825-828.

21 Walker, F.O., Dorovini-Zis, K., Young, A.B. and Penney, J.B., Evidence for neurotransmitter receptor changes in early Huntington's disease (HD), Neurology, 33 (1983) 149. 